

\section{DISCLAIMER}

This report was prepared as an account of work sponsored by an agency of the United States Government. Neither the United States Government nor any agency Thereof, nor any of their employees, makes any warranty, express or implied, or assumes any legal liability or responsibility for the accuracy, completeness, or usefulness of any information, apparatus, product, or process disclosed, or represents that its use would not infringe privately owned rights. Reference herein to any specific commercial product, process, or service by trade name, trademark, manufacturer, or otherwise does not necessarily constitute or imply its endorsement, recommendation, or favoring by the United States Government or any agency thereof. The views and opinions of authors expressed herein do not necessarily state or reflect those of the United States Government or any agency thereof. 


\section{DISCLAIMER}

Portions of this document may be illegible in electronic image products. Images are produced from the best available original document. 
Printed in the United States of America

Available from the U.S. Department of Energy

Office of Scientific and Technical Information

P.O. Box 62, Oak Ridge, Tennessee 37830

This report was prepared as an account of work sponsored by an agency of the United States Government. Neither the United States Government nor any agency thereof, nor any of their employees, makes any warranty, express or implied, or assumes any legal liability or responsibility for the accuracy. completeness, or usefulness of any information, apparatus, product, or process disclosed, or represents that its use would not infringe privately owned rights. Reference herein to any specific commercial product, process, or service by trade name, trademark, manufacturer, or otherwise, does not necessarlly constlitule ui imply its endorsement, recommendation, or favoring by the United States Government or any agency thereof. The views and opinions of authors expressed herein do not necessarily state or reflect those of the United States Government or any agency' thereof. 


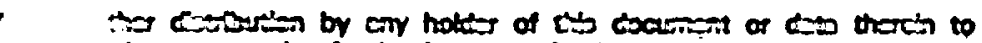

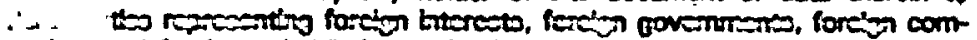

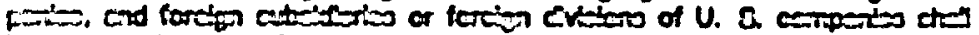

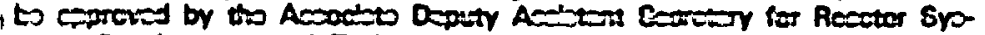

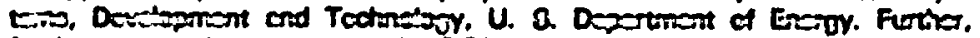

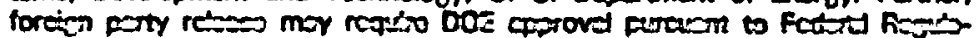

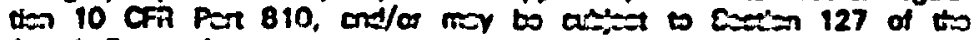
A:=-2 Enotor Act.

DOE-HTGR - 87-091

ORNL/TM- 10987

Distribution

Category UC-522:-

Metals and Ceramics Division

\title{
EXPERIMENTAL PLAN FOR IRRADIATION EXPERIMENT HRB-21
}

D. T. Goodin, M. J. Kania, and B. W. Patton

Date Published - April 1989

\author{
Prepared by the \\ OAK RIDGE NATIONAL LABORATORY \\ Oak Ridge, Tennessee 37831-6285 \\ operated by \\ MARTIN MARIETTA ENERGY SYSTEMS, INC. \\ for the \\ U.S. DEPARTMENT OF ENERGY \\ under contract DE-AC05-840R21400
}

DISCLAIMER
Ghis report was prepared as an account of work sponsored by an agency of the United States
Government. Neither the United States Government nor any agency thereof, nor any of their
hility for the accuracy, completeness, or usefulness of any information, apparatus, product, or
process disclosed, or represents that its use would not infringe privately owned rights. Refer-
ence herein to any specific commercial product, process, or service by tradc namc, trademark,
manufacturer, or otherwise does not necessarily constitute or imply its endorsement, recom-
mendation, or favoring by the United States Government or any agency thereof. The views
and opinions of authors expressed herein do not necessarily, state or reflect those of the
United States Government or any. agency thereof.




\section{DISCLAIMIER}

Portions of this document may be illegible in electronic image products. Images are produced from the best available original document. 


\section{CONTENTS}

LIST OF TABLES . . . . . . . . . . . . . . . . . . . . . . . . . . . v v

LIST OF FIGURES . . . . . . . . . . . . . . . . . . . . . . . . . . . . vii

ABSTRACT . . . . . . . . . . . . . . . . . . . . . . . . . . 1

1. SCOPE . . . . . . . . . . . . . . . . . . . . . . . . 2

2. OBJECTIVES . . . . . . . . . . . . . . . . . . . . . . . . . . . . 2

3. JUSTIFICATION . . . . . . . . . . . . . . . . . . . . . . . . 3

3.1 REFERENCE FUEL PERFORMANCE . . . . . . . . . . . . . . . . . 3

3.2 PERFORMANCE OF DEFECTIVE PARTICLES . . . . . . . . . . . . . . . 5

3.3 SORPTIVITY EXPERIMENTS . . . . . . . . . . . . . . . . . . . 5

$3.4 \mathrm{~B}_{4} \mathrm{C}$ SPECIMENS . . . . . . . . . . . . . . . . . . . . . . . . . 6

4. CAPSULE DESIGN AND DESCRIPTION . . . . . . . . . . . . . . . . . . 6

4.1 GENERAL CAPSULE DESIGN . . . . . . . . . . . . . . . . . . . 6

4.2 DESCRIPTION OF REFERENCE FUEL COMPACTS . . . . . . . . . . . . 11

4.3 DESCRIPTION OF ENCAPSULATED SPECIMENS . . . . . . . . . . . . . . . . . 13

4.3.1 Standard Fuel Particles . . . . . . . . . . . . . . . 14

4.3.2 Defective Fuel Particles . . . . . . . . . . . . . . 14

4.3.3 Sorptivity Specimens . . . . . . . . . . . . . . 16

4.3.4 Coated $\mathrm{B}_{4} \mathrm{C}$ Specimens . . . . . . . . . . . . . . . . . 18

4.3.5 Dosimetry and Flux Monitors . . . . . . . . . . . . . 19

5. IRRADIATION CONDITIONS . . . . . . . . . . . . . . . . . . . . . 19

5.1 IRRADIATION TEMPERATURE . . . . . . . . . . . . . . . . . . . 19

5.2 FUEL BURNUP . . . . . . . . . . . . . . . . . . . . . . . . . 19

5.3 FLUENCE . . . . . . . . . . . . . . . . . . . . . . . . . . . 21

6. POSTIRRADIATION EXAMINATION (PIE) . . . . . . . . . . . . . . . . . 21

6.1. CONDUCTION COOLDOWN TESTING . . . . . . . . . . . . . . . . . 24

7. TENTATIVE SCHEDULE . . . . . . . . . . . . . . . . . . . . 25

8. REFERENCES . . . . . . . . . . . . . . . . . . . . . . . 26 


\section{THIS PAGE}

\section{WAS INTENTIONALLY LEFT BLANK}




\section{LIST OF TABLES}

Table 4.1. Fuel loadings per graphite body . . . . . . . . . . . 9

Table 4.2. Capsule HBR-21 fuel compact dimensions and the total heavy-metal loading for 24 compacts to be irradiated in HRB-21 . . . . . 12

Table 4.3. HBR-21 encapsulated specimen test matrix . . . . . . . 13

Table 4.4. Sorptivity specimen test matrix for irradiation capsule HRB-21 including location and identification . . . . . . . . . . 17

Table 6.1. Tentative PIE test matrix for eight fuel compacts . . . 24

Table 6.2. Tentative CCT matrix for HRB-21 samples...... . . 25 


\section{THIS PAGE \\ WAS INTENTIONALLY \\ LEFT BLANK}




\section{LIST OF FIGURES}

Fig. 4.1. Horizontal section through irradiation capsule HRB - 21

Fig. 4.2. Vertical section through irradiation capsule HRB-21 . . 8

Fig. 4.3. Cross-section mock-up of irradiation capsule HRB-21

for thermal design calculational purposes: (a) horizontal cross section, R-O view, and (b) longitudinal cross section, R-Z view . . . 10

Fig. 4.4. Predicted failure fraction of bufferless particles as a function of irradiation time in irradiation capsule HRB-21. . . . . 15

Fig. 4.5. Unbonded particle holder used in capsule HRB-21 to contain standard and defective coated particles. All dimensions are in millimeters... . . . . . . . . . . . . . . . . . . . 15

Fig. 4.6. Particle holder for the evaluation of lumped burnable poison (LBP) and the reserve shutdown control (RSC)-coated $\mathrm{B}_{4} \mathrm{C}$ particles . . . . . . . . . . . . . . . . . . . . . . . . 18

Fig. 5.1. Thermocouple arrangement in irradiation capsule HRB -21

Fig. 5.2. Predicted fissile and fertile particle burnup profiles in capsule $\mathrm{HRB}-21$

Fig. 5.3. Predicted accumulated fast neutron fluence $(\mathrm{E}>29 \mathrm{fJ}$ ) in capsule HRB-21 . . . . . . . . . . . . . . . . . . . . 22 
EXPERIMENTAL PLAN FOR IRRADIATION EXPERIMENT HRB-21

D. T. Goodin, ${ }^{*}$ M. J. Kania, and B. W. Patton

\begin{abstract}
Irradiation experiment HRB-21 is the first in a series of test capsules that are designed to provide a fuel-performance data base to be used for the validation of modular hightemperature gas-cooled reactor (MHTGR) coated-particle fuel performance models under MHTGR normal operating conditions and specific licensing basis events. Capsule HRB-21 will contain an advanced TRISO-P UCO/ $\mathrm{ThO}_{2}$-coated-particle fuel system with demonstrated low defective-particle fraction $\left(\leq 5 \times 10^{-5}\right)$ and a heavy metal-contamination fraction $\left(\leq 1 \times 10^{-5}\right)$ that meets MHTGR quality specifications. The coated particles and fuel compacts were fabricated in laboratory-scale facilities using MHTGR reference procedures at General Atomics (GA). Nearly . 150,000 fissile and fertile particles will be irradiated in capsule HRB-21 at a mean volumetric fuel temperature of $975^{\circ} \mathrm{C}$ and will achieve a peak fissile burnup of $26 \%$ fissions per initial metal atom (FIMA) while accumulating a fast neutron fluence of about $4.5 \times 10^{25}$ neutrons $/ \mathrm{m}^{2}$.

This experiment is a cooperative effort between the U.S. Department of Energy (DOE) and the Japan Atomic Energy Research Institute (JAERI). The participants are the Oak Ridge National Laboratory (ORNL), GA, and the Tokai Research Establishment. Capsule HRB-21 will contain the U.S. MHTGR fuel specimens, and a companion capsule, HRB-22, will contain the JAERI fuel. The irradiation will take place in the removable beryllium reflector facility of the High Flux Isotope Reactor (HFIR) at ORNL. The performance of the fuel during irradiation will be closely monitored through on-line fission gas release measurements. Detailed postirradiation examination and conduction cooldown simulation testing will be performed on the irradiated fuel compacts from both the HRB-21 and HRB-22 capsules.
\end{abstract}

* On assignment to Oak Ridge National Laboratory from General Atomics (GA) from October 1, 1986, through September 30, 1987. 


\section{SCOPE}

The HRB-21 irradiation experiment will provide data for the development of the modular high-temperature gas-cooled reactor (MHTGR) in accordance with the MHTGR plant fuel/fission product technology development plan. ${ }^{1}$ The test is a cooperative effort of the U.S. Department of Energy (DOE) and the Japan Atomic Energy Research Institute (JAERI). The participants are the Oak Ridge National Laboratory (.ORNL), General Atomics (GA), and the Tokai Research Establishment. The HRB-21 capsule will contain 24 fuel compacts of U.S. MHTGR reference quality fuel as well as a variety of encapsulated specimens related to MHTGR fuel performance; fission-product transport, and control materials. A companion capsule designated HRB-22 will contain the JAERI fuel. The HRB-21 capsule will be designed and assembled by ORNL. The fuel compacts, graphite body assemblies, and certain encapsulated specimens will be provided by GA. The irradiation will take place in the removable beryllium reflector area of the High Flux Isotope Reactor (HFIR) at ORNL. The performance of the fuel during irradiation will be monitored by on-line fission gas release measurements. Postirradiation examinations and conduction cooldown simulation testing will be performed with the HRB-21 fuel compacts.

\section{OBJECTIVES}

The primary objectives of the HRB-21 irradiation experiment are (1) to determine the performance of U.S. (HRB-21) and JAFRI (HRB-22) low-enricheduranium (LEU)-coated-particle fuels under irradiation conditions and (2) to provide samples for postirradiation testing to determine the capability of the particles to meet criteria on failure-fraction limits under accident conditions. The detailed objectives are

1. provide the first in-reactor test of U.S. fuel meeting MHTGR fuelquality specifications and provide a portion of the data necessary to validate the U.S. reference fuel performance models under normal operating conditions; 
2. provide a portion of the samples needed for a series of conduction and cooldown simulation tests designed to update, as necessary, and validate the U.S. reference fuel performance model under conditions called licensing basis events (LBE);

3. provide in-reactor coating failure data for potential revision of the defective-particle performance models;

4. provide irradiated unbonded particles of MHTGR reference quality for (a) direct comparison to defective particle performance in-reactor and (b) selected postirradiation investigations of the structure and performance of reference fuel;

5. provide data on partition coefficients and sorptivity isotherms of $\mathrm{Cs}_{s}$, $\mathrm{Sr}, \mathrm{I}$, and $\mathrm{Ag}$ on MHTGR core materials;

6. provide data on the irradiation performance of both PyC-coated and PyC/SiC-coated particles containing $\mathrm{B}_{4} \mathrm{C}$; and

7. under the auspices of the U.S./Federal Republic of Germany (FRG) umbrella agreement for cooperation in gas-cooled reactor (GCR) development, fuel fission products and graphite subprogram, PWS-FD-25, to provide significant fuel performance data for exchange with the FRG in return for the irradiation of the HFR-B1 capsule.

Experiment HRB-21 will be conducted in accordance with 10CFR50/B requirements for quality assurance as specified in Appendix $A$ of the fuel/fission products technology development plan. Fuel test specimens prepared at GA followed nuclear quality assurance-1 (NQA-1) requirements, and the fuel characterization will be documented in a preirradiation report. The experimental test plan, capsule design and fabrication, irradiation and monitoring, postirradiation tests and examinations, and final documentation will be performed at ORNL in accordance with NQA-1 requirements as documented in the ORNL quality assurance manual.

\section{JUSTIFICATION}

\subsection{REFERENCE FUEL PERFORMANCE}

The ceramic fuel of the MHTGR has been studied for nearly three decades, and the fundamental performance characteristics and 
fission-product release mechanisms are well understood. The high temperature stability of the MHTGR fuel and the retention of fission products under both normal and off-normal operating conditions have been demonstrated. Validation of the fuel performance models that are used to predict the coated-particle integrity is the primary task remaining to be accomplished.

Although the existing data base is extensive, the MHTGR uses an advanced fuel (TRISO-P $\mathrm{UCO} / \mathrm{ThO}_{2}$ ), and the existing performance models are largely based on data from different fuel systems. In addition, the quality specifications for the MHTGR fuel are more stringent than those in previous plants. Thus, certain assumptions and extrapolations were required so that the existing data base for the MHTGR could be used. In making these assumptions, the uncertainty in the performance descriptions increased. In the case of particle coating failure fraction, this increase in the uncertainty is unacceptably large with regard.to compliance with site-boundary dose limits. ,Reduction of this uncertainty to specified values constitutes validation of the performance models. This is to be accomplished for normal operating conditions by a series of irradiation capsules and postirradiation examinations, using reference quality fuel to provide a statistically significant evaluation of the models in comparison with the data.

The HRB-21 capsule will also furnish reference quality irradiated samples for use in conduction cooldown tests (CCT). Although there is an extensive data base from the prior core heatup simulation testing (CHST) program, the CHST program was intended to simulate the conditions for a loss of cooling event in a large [2240 MW(t)] HTGR design. Typically, the CHST simulation transients consisted of heating ramps from 1100 to $2500^{\circ} \mathrm{C}$ in time periods of about $30 \mathrm{~h}$. In contrast, the MHTGR LBEs involve temperatures of less than $1600^{\circ} \mathrm{C}$ but for longer times. Thus, the U.S. data base that was developed for the large HTGR is lacking in the intermediate temperature range $\left(1200\right.$ to $\left.1600^{\circ} \mathrm{C}\right)$ that is of most importance for the MHTGR. Therefore, the present U.S. reference fuel failure model is heavily dependent on the test results of particles manufactured in the FRG. Testing of U.S. fuels is needed to validate the model for use with fuel 
manufactured in the United States with MHTGR reference quality specifications and for use in prismatic cores. This is to be accomplished by a series of postirradiation heating tests of complete fuel compacts within graphite bodies (as irradiated) at temperatures in the range of 1400 to $1800^{\circ} \mathrm{C}$. These tests will include conditions characteristic of air and. water ingress LBEs for the MHTGR.

\subsection{PERFORMANCE OF DEFECTIVE PARTICLES}

The term "defective particle" refers to as-fabricated particles that have at least one intact coating and one or more missing or defective (e.g., cracked or penetrated) coating layers. The most important example of a defective particle is one with a missing buffer layer. Such particles are not expected to release fission products initially during irradiation but have a higher probability of failure as burnup proceeds because of the increased internal pressure associated with the lack of void volume normally provided by the buffer layer. Analytical models based on fundamental materials property data are used to calculate the pressure-induced stress buildup and the consequent probability for failure: This analytical calculation has an estimated upper $95 \%$ confidence limit of ten times the calculated value. Therefore, specific test data for defective particles are needed with which to normalize the model calculation.

\subsection{SORPTIVITY EXPERIMENTS}

To describe the transport through and release from the core of the MHTGR, data are needed on the sorptivity of fission products on the core materials. For highly graphitic materials, the sorptivity will change as a function of neutron fluence, graphite burnoff, and temperature. Data are lacking for the fission product $\mathrm{Ag}$, and additional data as a function of burnoff are needed for $\mathrm{Cs}, \mathrm{Sr}$, and I. The sorptivity is usually expressed in terms of the relationship between the partial vapor pressure of the fission product and the concentration of the metallic fission product in the sorbent: By use of encapsulated sorptivity specimens in HRB-21, the partition coefficient (the ratio of the concentration of a selected fission product in one phase to the concentration in another phase) can be 
determined. This partition coefficient method can lead to the determination of the absolute sorption isotherm when evaluated in conjunction with known isotherms. The HRB-21 partition coefficient specimens will provide a necessary comparison of direct in-reactor data to data from out-of-reactor sorptivity experiments.

\section{$3.4 \quad B_{4} C$ SPECIMENS}

Granules of $\mathrm{B}_{4} \mathrm{C}$ are utilized in the lumped burnable poison (LBP) and the reserve shutdown control (RSC) pellets of the MHTGR. In the event of an air ingress, uncoated $\mathrm{B}_{4} \mathrm{C}$ may undergo preferential oxidation of $\mathrm{B}_{4} \mathrm{C}$ to form $\mathrm{B}_{2} \mathrm{O}_{3}$. . The $\mathrm{B}_{2} \mathrm{O}_{3}$ layer forms around each $\mathrm{B}_{4} \mathrm{C}$ granule, and then the rate of reaction slows unless the $\mathrm{B}_{2} \mathrm{O}_{3}$ layer is removed by vaporization. The boiling point for $\mathrm{B}_{2} \mathrm{O}_{3}$ is $1250^{\circ} \mathrm{C}$; thus, the vaporization will be rapid under conduction cooldown conditions as well as at the higher normal. operating temperatures. In the event of water ingress, the $\mathrm{B}_{2} \mathrm{O}_{3}$ reacts with water to form $\mathrm{H}_{3} \mathrm{BO}_{3}$ (boric acid) which is volatile at temperatures as low, as $300^{\circ} \mathrm{C}$.

The MHTGR will utilize pyrocarbon or SiC-coated $\mathrm{B}_{4} \mathrm{C} \cdot$ granules to inhibit oxidation of the LBP and RSC. The selected coating processes and specifications for $\mathrm{B}_{4} \mathrm{C}$ must be shown as acceptable during fabrication, irradiation, and postirradiation heating. Encapsulated $\mathrm{B}_{4} \mathrm{C}$ particles will be irradiated in HRB-21 to assure the irradiation performance of the LBP and RSC materials.

\section{GAPSULE DESIGN AND DESCRIPTION}

\subsection{GENERAL CAPSULE DESIGN}

The HRB-21 irradiation capsule consists of a doubly contained, single purged cell with fuel compacts surrounded by H-451 graphite bodies (Fig. 4.1). The fuel compacts, three per graphite body, are composed of TRISO-P-coated UCO and $\mathrm{ThO}_{2}$ particles embedded in graphite matrix material. The eight graphite bodies are contained within two Inconel 718 containment tubes (Fig. 4.2) designed to independently withstand $6.9 \mathrm{MPa}$ (1000 psi) 


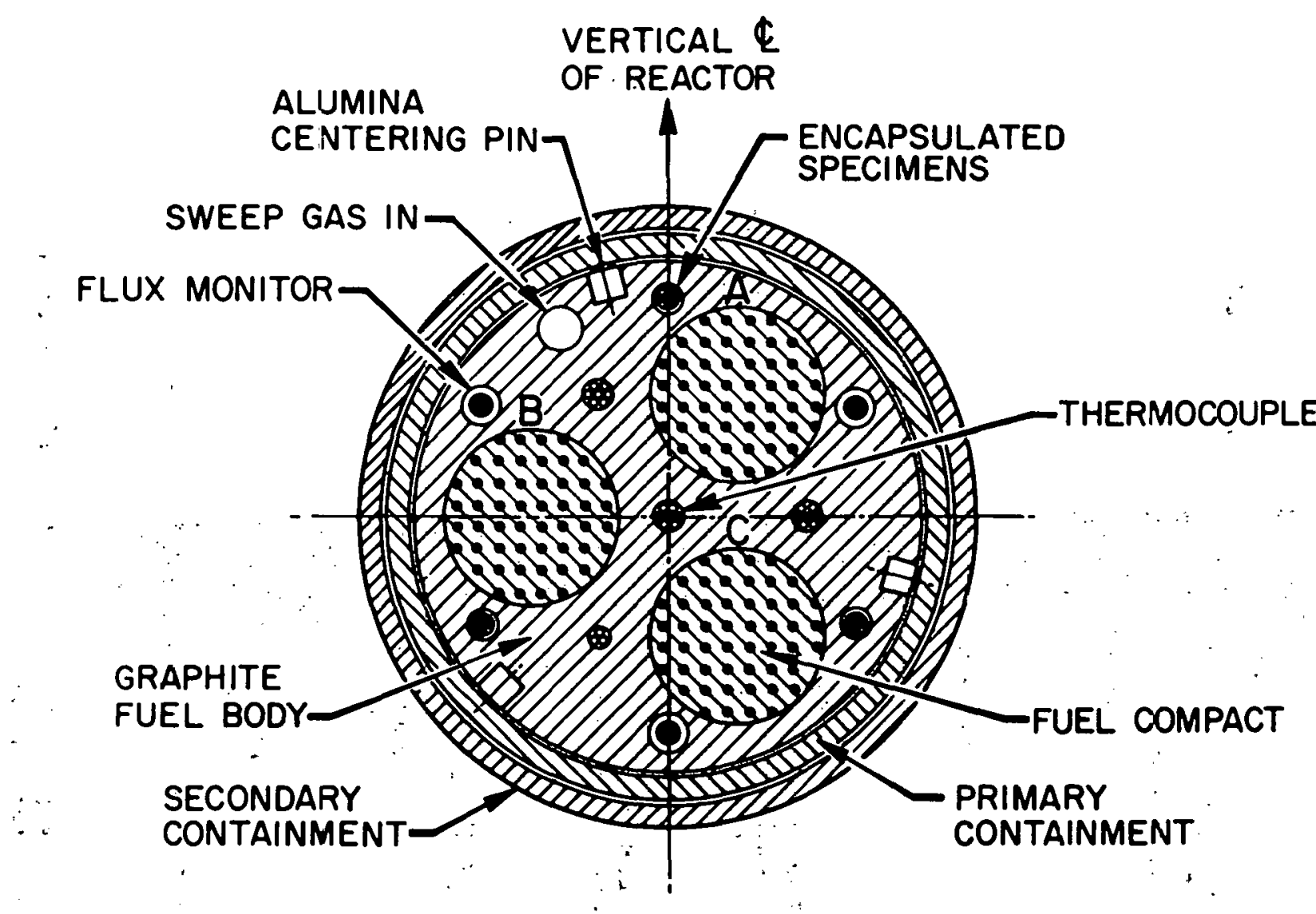

HORIZONTAL SECTION THROUGH CAPSULE HRB-21

Fig. 4.1. Horizontal section through irradiation capsule HRB-21. 


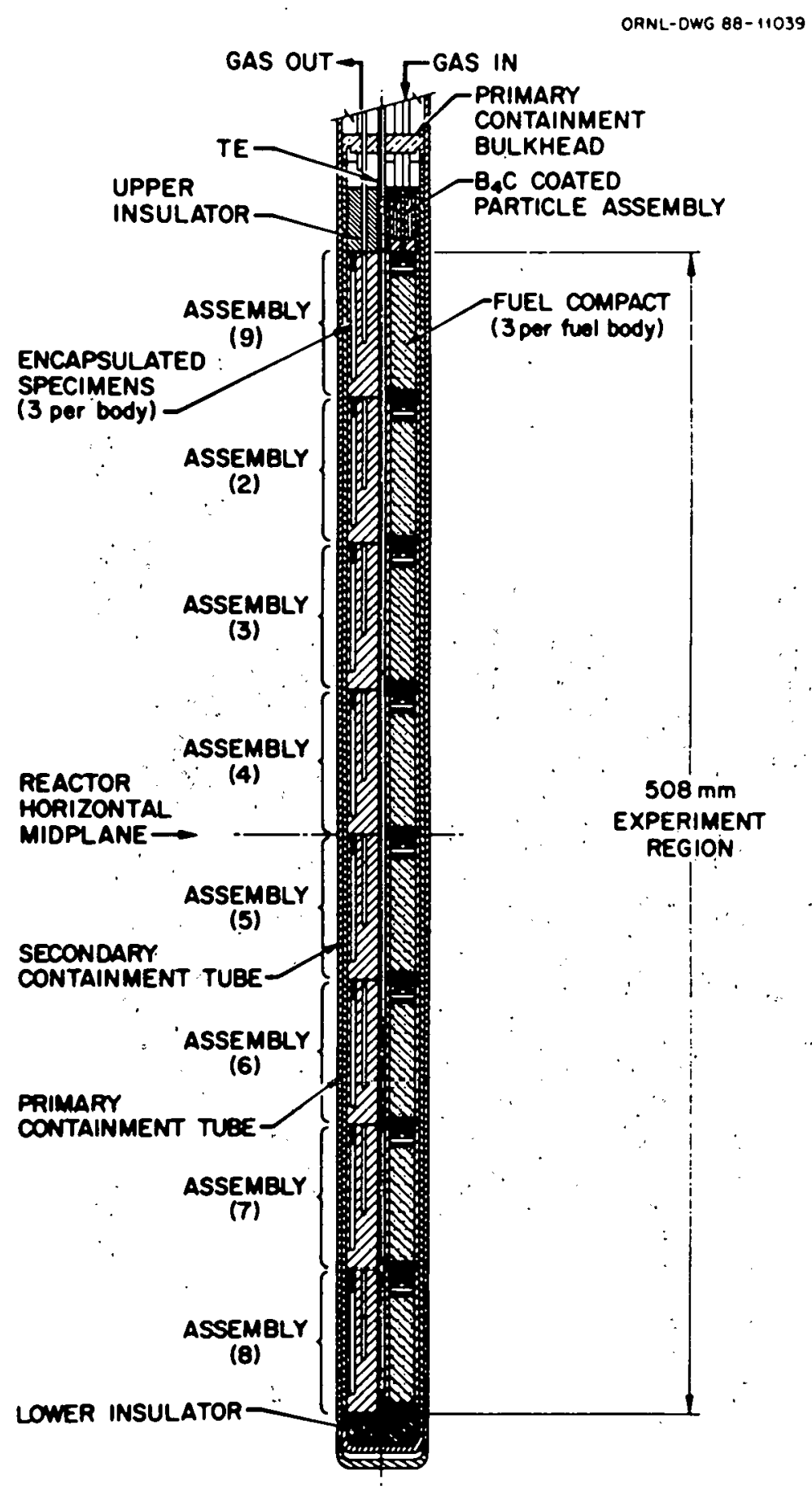

Fig. 4.2. Vertical section through irradiation capsule HRB- 21 . 
inside or outside. During HFIR operation, pure helium at $4.14 \mathrm{MPa}$ (600 psi) flows between the primary and secondary Inconel containments. A gas mixture of helium and neon flows between the primary Inconel contain:ment and the graphite body surface. By varying this gas mixture within the primary containment, the radial conductance of heat to the surrounding HFIR cooling water system is controlled, and the operating temperature of the fuel compacts may be regulated. The entire capsule is fitted with an outer aluminum liner designed to protect the HFIR beryllium reflector.

The use of Inconel. 718 in place of the stainless steel 304 containment, used in earlier HRB capsules, allows an increase in the linear heat rate of 49 to $65 \mathrm{~kW} / \mathrm{m}$ ( 15 to $20 \mathrm{~kW} / \mathrm{ft}$ ). The increased heat rate allows irradiation of a larger number of particles. This is especially important for HRB-21, because large sample sizes are needed to validate the very low failure-fraction expectations for MHTGR reference quality fuel. The HRB-21 fuel loadings per graphite body are given in Table 4.1.

Table 4.1. Fuel loadings per graphite body

\begin{tabular}{|c|c|c|c|c|c|c|}
\hline \multirow{2}{*}{$\begin{array}{l}\text { Graphite } \\
\text { body number }\end{array}$} & \multicolumn{4}{|c|}{ Total fuel loading (g) } & \multirow{2}{*}{$\begin{array}{r}\text { Fissile } \\
\text { particles }\end{array}$} & \multirow{2}{*}{$\begin{array}{r}\text { Fertile } \\
\text { particles }\end{array}$} \\
\hline & $235 \mathrm{U}$ & $238 \mathrm{U}$ & U-total & $232 \mathrm{Th}$ & & \\
\hline 9,8 & 0.288 & 1.173 & 1.466 & 7.500 & 6,700 & 13,310 \\
\hline 2,7 & 0.239 & 0.975 & 1.214 & 7.500 & 5,540 & 13,310 \\
\hline 3,6 & 0.176 & 0.716 & 0.891 & 7.500 & 4,070 & 13,310 \\
\hline \multirow[t]{2}{*}{4,5} & 0.146 & 0.594 & 0.740 & 7.500 & 3,380 & 13,310 \\
\hline & & Totals & ( 8 Bodies & s) $=$ & 39,380 & 106,480 \\
\hline
\end{tabular}

The HRB-21 design thermal analysis was performed with the HEATING6 code, ${ }^{2}$ which uses a three-dimensional model in cylindrical coordinates. The model consists of a graphite holder with insulated boundary conditions on the top, bottom, and plianes of symmetry as illustrated in Fig. 4.3. The graphite body dimensions for capsule HRB-21 have been determined using a two-dimensional heat transfer analysis. The radial gaps between the 


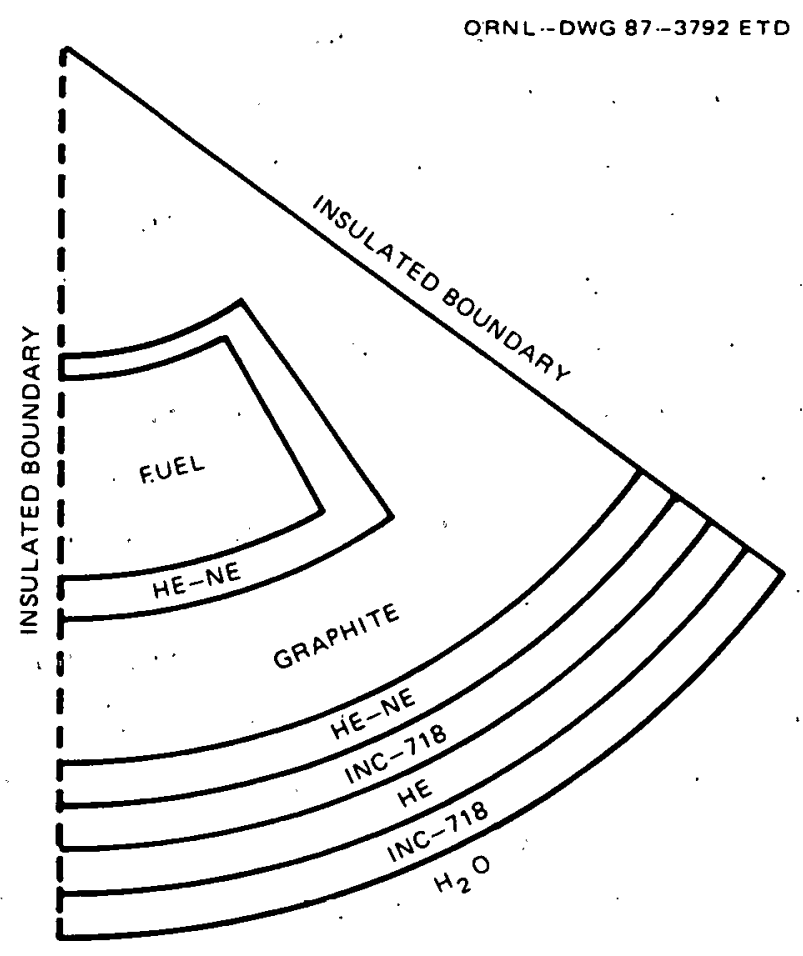

(a) R-QVIEW

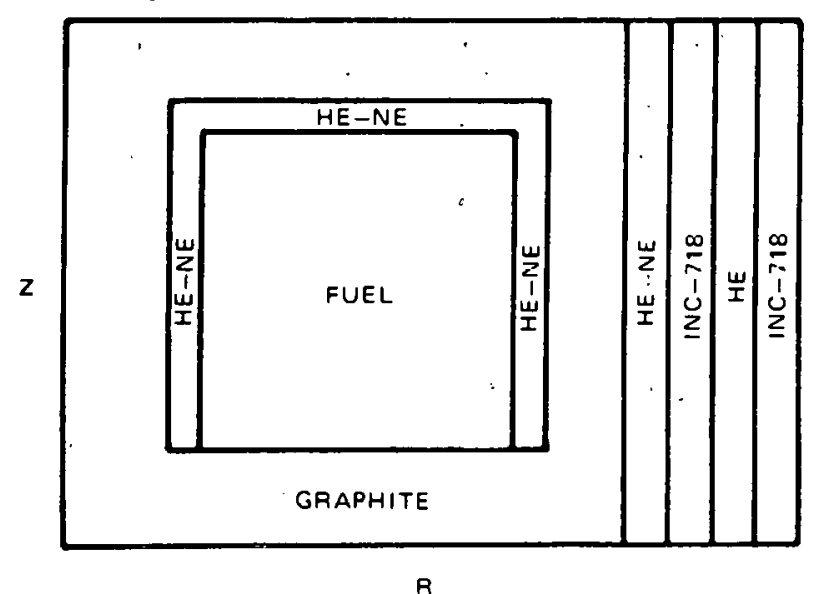

(b) R-Z VIEW

Fig. 4.3. Cross-section mock-up of irradiation capsule HRB-21 for thermal design calculational purposes: (a) horizontal cross section, $R-0$ view, and

(b) longitudinal cross section, R-Z view. 
graphite holders and the primary containment wall at operating temperature are as follows:

\begin{tabular}{ccc} 
Graphite fuel body & & $\frac{\text { Radial gap (mm) }}{1}$ \\
\hline 9,8 & & 0.203 \\
2,7 & & 0.178 \\
3,6 & 0.127 \\
4,5 & & 0.127
\end{tabular}

All thermocouples in HRB-21 will be placed within the graphite bodies. A total of 24 junctions will be used to monitor the graphite temperatures in four separate thermocouple array assemblies (TCAT).

\subsection{DESCR:IPTION OF REFERENCE FUEL COMPACTS}

The fuel compacts were fabricated and placed within the graphite bodies by,GA. Table 4.2 lists the dimensions, weight, and heavy-metal content for each of the fuel compacts used in capsule HBR-21. The reference MHTGR fuel compacts are made by a hot-injection process. This consists of injecting a viscous mixture of binder, binder additive, and graphite filler at temperatures of 150 to $200^{\circ} \mathrm{C}$ into a closely packed array of coated fuel particles and inert $\mathrm{H}-451$ graphite shim particles contained in a cylindrical mold. The nominal injection pressure has been $6.9 \mathrm{MPa}$ (1000 psi), but was decreased for HBR-21 compact manufacture to reduce particle-to-particle interactions so that the levels of manufacturing-induced coating defects would be decreased.

Petroleum-derived pitch is used as a binder phase, and graphite powder is used for the filler. The as-injected compacts are then heat treated in incremental temperature steps to approximately $1750^{\circ} \mathrm{C}$ to carbonize the binder phase, drive off volatile gases and impurities, and stabilize the dimensions of the compacts.

The HRB-21 fuel particles are TRISO-P-coated UCO and $\mathrm{ThO}_{2}$ particles with reference. MHTGR dimensions that were produced in the $240-\mathrm{mm}$ development coater in August and September $1986 .^{3}$ The coated particles will be 
Table 4.2. Capsule HBR-21 fuel compact dimensions and the total heavymetal loading for 24 compacts to be irradiated in HRB-21

\begin{tabular}{|c|c|c|c|c|c|c|c|c|}
\hline \multirow{2}{*}{$\begin{array}{l}\text { Position } \\
\text { from top } \\
\text { of capsule }\end{array}$} & \multirow{2}{*}{ Hole } & \multicolumn{3}{|c|}{$\begin{array}{l}\text { Outer diameter } \\
\qquad(\mathrm{mm})\end{array}$} & \multirow{2}{*}{$\begin{array}{l}\text { Length } \\
(\mathrm{mm})\end{array}$} & \multirow{2}{*}{$\begin{array}{l}\text { Weight } \\
\text { (g) }\end{array}$} & \multirow{2}{*}{$\begin{array}{l}\text { U total } \\
(\mathrm{g})\end{array}$} & \multirow{2}{*}{$\begin{array}{c}\text { Th total } \\
(\mathrm{g})\end{array}$} \\
\hline & & Top & Middle & Bottom & & & & \\
\hline \multirow[t]{3}{*}{1} & A & 12.45 & 12.46 & 12.30 & 49.13 & 10.651 & 0.516 & 2.355 \\
\hline & B & 12.45 & 12.43 & 12.27 & 49.19 & 10.666 & 0.516 & 2.355 \\
\hline & C & 12.46 & 12.45 & 12.30 & 49.22 & 10.667 & 0.516 & 2.355 \\
\hline \multirow[t]{3}{*}{2} & A & 12.48 & 12.47 & 12.37 & 49.28 & 10.655 & 0.402 & 2.540 \\
\hline & B & 12.44 & 12.47 & 12.35 & 49.30 & 10.676 & 0.402 & 2.540 \\
\hline & C & 12.45 & 12.45 & 12.35 & 49.26 & 10.691 & 0.402 & 2.540 \\
\hline \multirow[t]{3}{*}{3} & A & 12.48 & 12.46 & 12.38 & 49.28 & 10.581 & 0.298 & 2.540 \\
\hline & B & 12.46 & 12.44 & 12.39 & 49.29 & 10.597 & 0.298 & 2.540 \\
\hline & C & 12.46 & 12.43 & 12.33 & 49.30 & 10.591 & 0.298 & 2.540 \\
\hline \multirow[t]{3}{*}{4} & A & 12.46 & 12.47 & 12.31 & 49.32 & 10.527 & 0.248 & 2.500 \\
\hline & B & 12.51 & 12.46 & 12.32 & 49.32 & 10.482 & 0.248 & 2.500 \\
\hline & $\mathrm{C}$ & 12.48 & 12.46 & 12.32 & 49.32 & 10.505 & 0.248 & 2.500 \\
\hline \multirow[t]{3}{*}{5} & A & 12.50 & 12.46 & 12.33 & 49.33 & 10.522 & 0.248 & 2.500 \\
\hline & B & 12.49 & 12.45 & 12.35 & 49.33 & 10.511 & 0.248 & 2.500 \\
\hline & c & 12.49 & 12.50 & 12.34 & 49.32 & 10.517 & 0.248 & 2.500 \\
\hline \multirow[t]{3}{*}{6} & A & 12.44 & 12.46 & 12.35 & 49.35 & 10.589 & 0.298 & 2.540 \\
\hline & B & 12.46 & 12.43 & $12: 37$ & 49.32 & 10.583 & 0.298 & 2.540 \\
\hline & C & 12.46 & 12.45 & 12.35 & 49.28 & 10.574 & 0.298 & 2.540 \\
\hline \multirow[t]{3}{*}{7} & A & 12.46 & 12.41 & 12.37 & 49.33 & 10.660 & 0.402 & 2.540 \\
\hline & B & 12.47 & 12.43 & 12.35 & 49.33 & 10.676 & 0.402 & 2.540 \\
\hline & $C$ & 12.46 & 12.43 & 12.38 & 49.26 & 10.703 & 0.402 & 2.540 \\
\hline \multirow[t]{3}{*}{8} & A & 12.45 & 12.44 & 12.32 & 49.22 & 10.655 & 0.516 & 2.355 \\
\hline & B & 12.45 & 12.45 & 12.33 & 49.22 & 10.646 & 0.516 & 2.355 \\
\hline & C & 12.45 & 12.44 & 12.31 & 49.16 & 10.636 & 0.516 & 2.355 \\
\hline
\end{tabular}

fabricated into fuel compacts, and companion samples. will be tested prior to irradiation to ensure that compacts are consistent with the MHTGRreference fuel quality specifications with respect to manufacturing defects:

Manufacturing defect
missing or defective:
Buffer
IPyC
SiC
OPyC

$\begin{array}{cc}\begin{array}{c}\text { Defect fraction } \\ \text { (508 confidence) } \\ \text { on mean }\end{array} & \frac{\begin{array}{c}\text { Defect fraction } \\ (958 \text { confidence) } \\ \text { on mean }\end{array}}{5.0 \mathrm{E}-05} \\ 4.0 \mathrm{E}-05 & 2.0 \mathrm{E}-04 \\ 5.0 \mathrm{E}-05 & 1.0 \mathrm{E}-04 \\ 1.0 \mathrm{E}-04 & 1.0 \mathrm{E}-04 \\ & 1.0 \mathrm{E}-03\end{array}$


The compacts will have a heavy-metal contamination of less than 1.0E-05 (50\% confidence on mean) and 2.0E-05 (95\% confidence on mean). Initial release to birth ( $R / B$ ) ratios will be determined for the unirradiated compacts by a low-flux irradiation in the GA TRIGA reactor.

\subsection{DESCRIPTION OF ENCAPSULATED SPECIMENS}

Each of the HRB-21 capsule graphite bodies includes three 2.38-mm-diam (0.094-in.) encapsulated specimen ("piggyback") holes (Fig. 4.1). The samples to be irradiated will be sealed within niobium tubes $51 \mathrm{~mm}$ long by $2.21 \mathrm{~mm}$ diam that will be placed in these specimen holes. A schematic of the general loading arrangement for these specimens is shown in Table 4.3, and the various sample types are described in the next section.

Table 4.3. HBR-21 encapsulated specimen test matrix

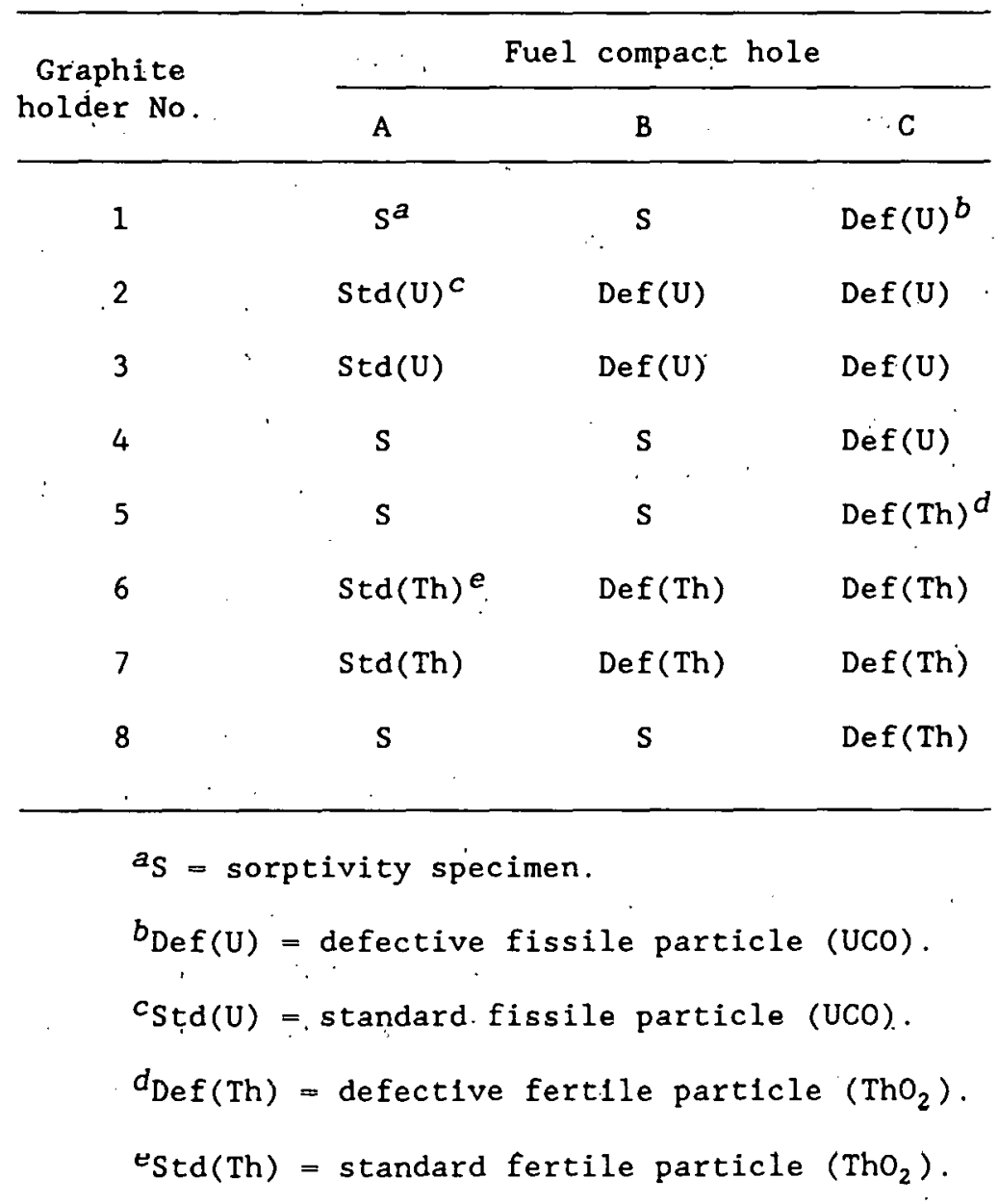




\subsubsection{Standard. Fue1 Particles}

'Samples of unbonded fissile and fertile fuel particles selected from the reference fuel fabrication batches will be irradiated in a portion of the holes within the graphite bodies in positions $2,3,6$, and 7 (Table 4.3). The standard particle irradiation results will be compared with those for defective particles. 'The standard particles will'be available for selected postirradiation analyses and investigations. regarding materials performance and fission-product transport.

\subsubsection{Defective Fuel Particles}

Particles with missing buffer, layers are predicted to be the most significant contributors, to fission product release during LBEs involving conduction cooldown or water ingress in the MHTGR. Data are needed for potential revision of the bufferless particle-failure model to reduce the uncertainty associated with' the present correlation. 'Whereas separate purged cells in future irradiation capsules will be devoted entirely to investigation of bufferless particle performance, supplementary data can be provided in a timely fashion.by the addition of bufferless particleencapsulated specimens to the HRB-21 experiment.

Bufferless particles are expected to fail earlier than standard particles because of excessive pressure buildup within the particle in the absence of the void volume normally supplied by the buffer layer. The predicted bufferless particle-failure fraction as a function of irradiation time in capsule HRB-21 is shown in Fig. 4.4 for fissile and fertile particles. Given the brittle nature of the primary load-bearing layer of the particle (the $S i C$ ), the failure mechanism will likely be a sudden, catastrophic failure of all coating layers. In the case of a bed of unbonded particles, the failure of a single particle is possible, which may result in the failure of an adjacent, highly stressed particle due to load transference. Thus, all bufferless particles will be loaded into individually drilled holes of a POCO graphite crucible to provide separation and shock insulation (Fig. 4.5). This configuration simulates the separation afforded to the bufferless particles by the matrix material of the MHTGRreference fuel compact. . The particles will be protected from contact with 

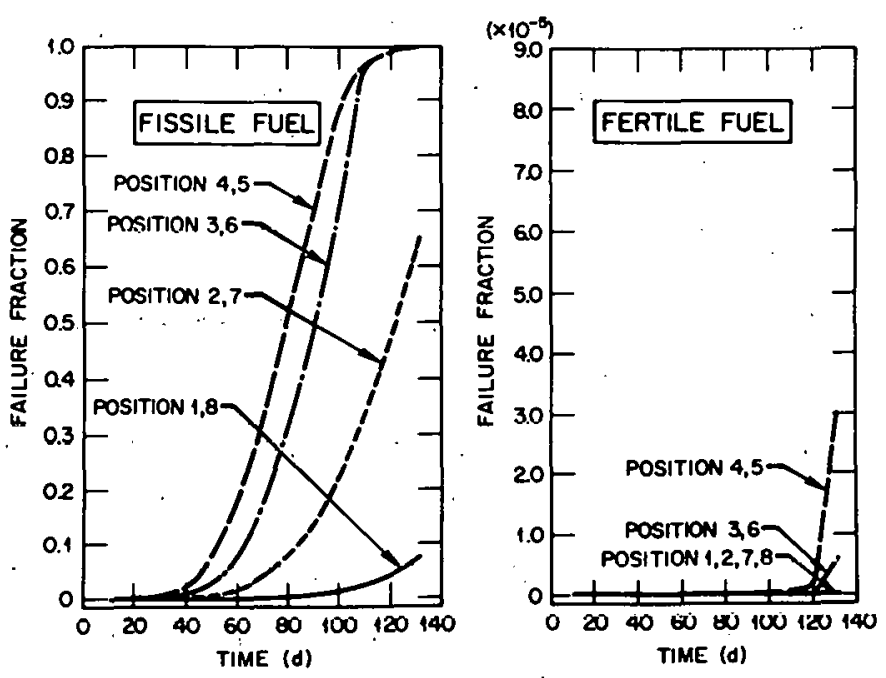

Fig. 4.4. Predicted failure fraction. of bufferless particles as a function of irradiation time in irradiation capsule HRB- 21 .

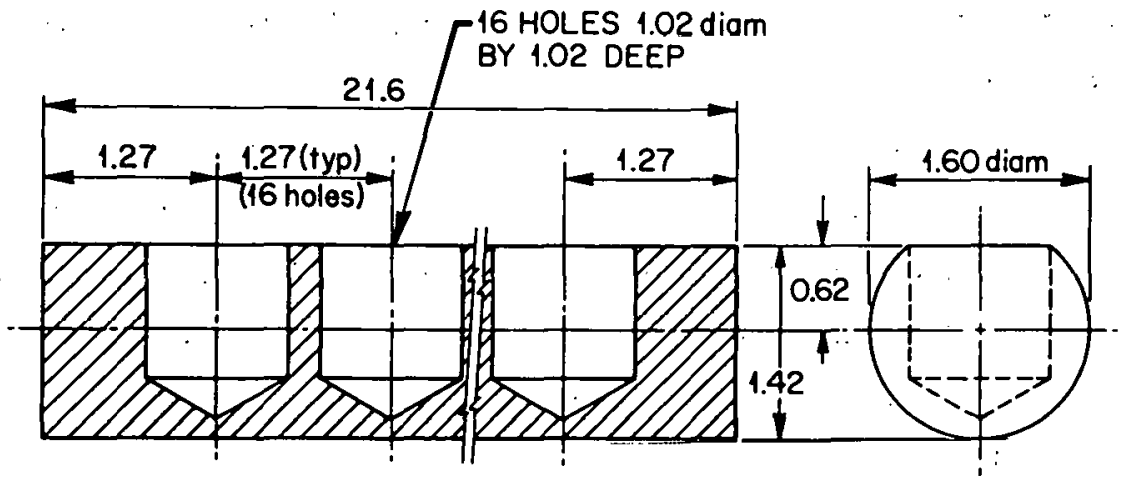

MATERIAL: POCO AXF-50-1 GRAPHITE NOTE: EACH SEALED Nb TUBE SAMPLE CONTAINS

TWO GRAPHITE LOOSE-PARTICLE HOLDERS, SHOWN ABOVE.

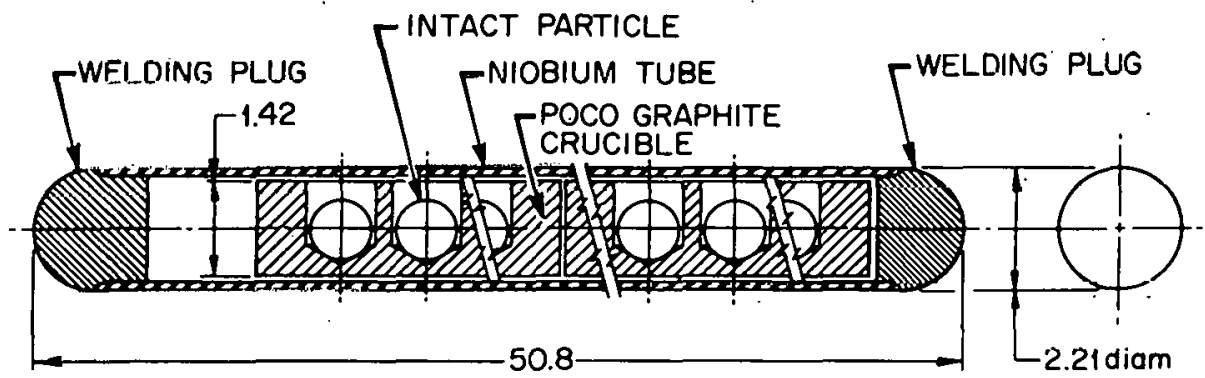

Fi.g. 4.5. Unbonded particle holder used in capsule HRB-21 to contain standard and defective coated particles. All dimensions are in millimeters. 
the niobium containment tube by placing a strip of graphite foil in a groove covering the particle holes. As shown in Table 4.3, the defective particle samples will be irradiated in a portion of the holes within each of the graphite bodies.

\subsubsection{Sorptivity Specimens}

An array of in-reactor sorptivity experiments will allow determination of the partition coefficients of several selected fission products on core materials as a function of temperature, fast neutron fluence, fissionproduct concentration, and material and extent of material oxidation. The method consists of encapsulating several solid materials in a smal1 niobium tube along with a known quantity of a fission product. The system inreactor consists of a gaseous phase and several solid phases, and the system undergoes a redistribution of fission products as irradiation damage occurs and approaches a thermodynamic equilibrium. The sorptivity specimen must be designed and constructed so that the gas-phase concentration is sufficiently small such that, upon cooling from the relatively high temperature of the experiment, the gaseous fission products condensing on the solid phases do not appreciably alter the distribution established at the higher temperatures.

The sorptivity specimens are to be placed in the graphite fuel bodies in positions $1,4,5$, and 8 (Table 4.3). The experimental arrangement of the specimens consists of eight positions, two each in positions 1 and 4 in the upper half of the capsule and two each in positions 5 and 8 in the lower half of the capsule. Positions 1 and 8 and 4 and 5 are.symmetric. The sorptivity specimen test matrix is presented in detail in Table 4.4 for each irradiation position. A total of 28 specimens will be irradiated in $\mathrm{HRB}-21$, and 16 specimens will be heated out-of-reactor in laboratory experiments at ORNL. The latter specimens are designated by the "NA" under column heading "Graphite Body Position" in Table 4.4. All of the specimens will be encapsulated in niobium tubes, backfilled with helium, and hermetically sealed prior to positioning in the graphite fuel bodies.

The H-451 graphite and fuel matrix samples will be obtained via coring of larger pieces of graphite and unfueled compacts. The Pyc samples are 
Table 4.4. Sorptivity specimen test. matrix for irradiation capsule HRB-21 including location and identification ${ }^{a}$

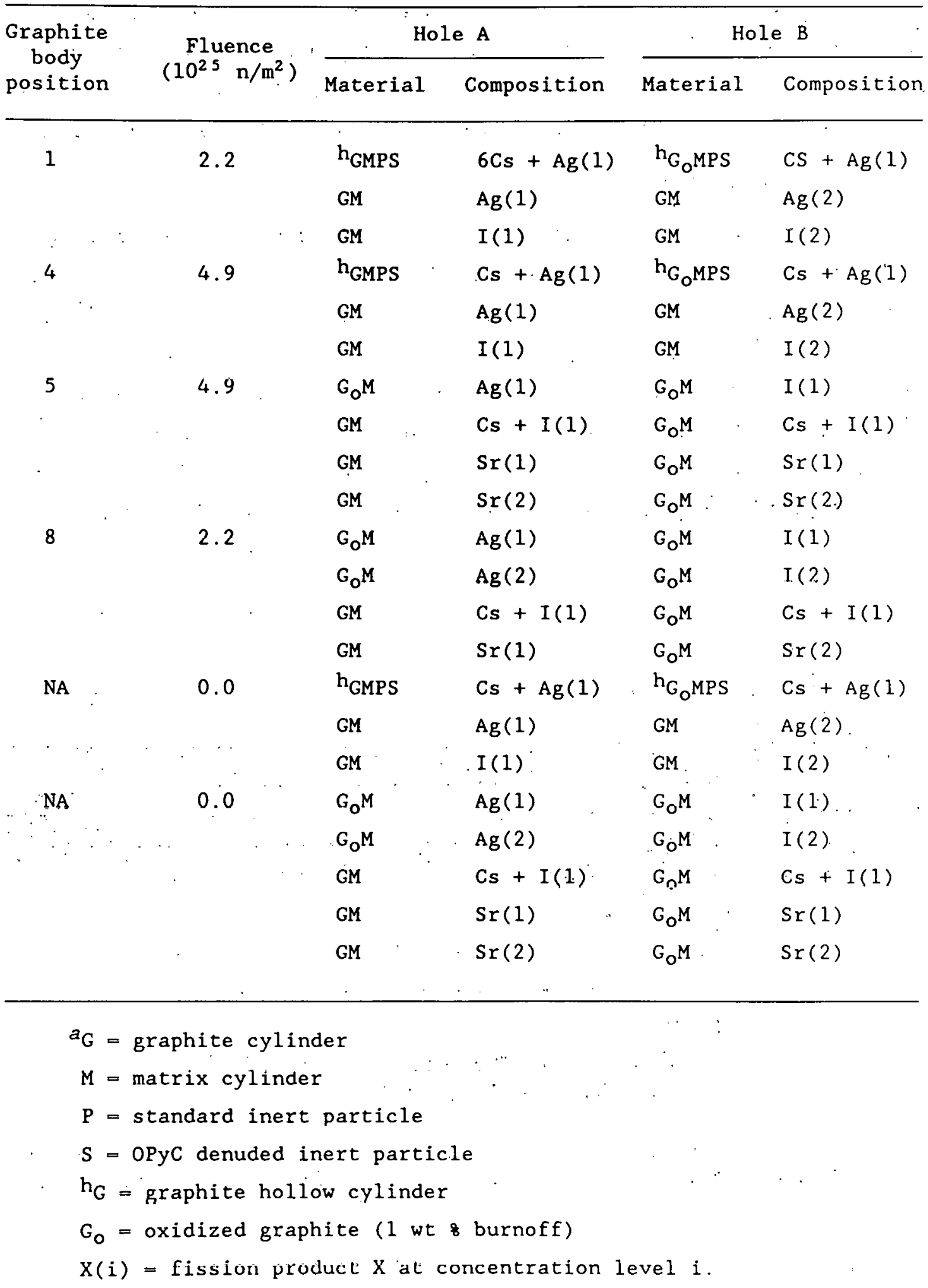


inert fuel particles, and the SiC samples are TRISO-P-coated inert particles with their BISO-coated outer PyC coating removed. The fission products are added to the graphite or matrix material by soaking it in a solution of the desired fission products, drying, and then heating the material to drive off the volatile components of the solution. The samples are sealed in a niobium capsule under a helium environment at 1 atm.

\subsubsection{Coated $\mathrm{B}_{4} \mathrm{C}$ Specimens}

The coated $\mathrm{B}_{4} \mathrm{C}$ particles consist of two types. One batch of particles is PyC coated, and the other is coated with PyC/SiC coating. The particles will be placed within 5.1-mm-OD POCO graphite crucibles with a length of $28 \mathrm{~mm}$ (Fig: 4.6). Each graphite crucible will be loaded with approximately 170 particles of each $\mathrm{B}_{4} \mathrm{C}$ particle type. Six of the $\mathrm{B}_{4} \mathrm{C}$ crucibles will then be located in the upper insulator of the HRB-21 capsule. This insulator is located just above the top graphite fuel body-fuel position and is approximately $260 \mathrm{~mm}$ above the HFIR horizontal midplane.

ORNL-DWG 88-11614

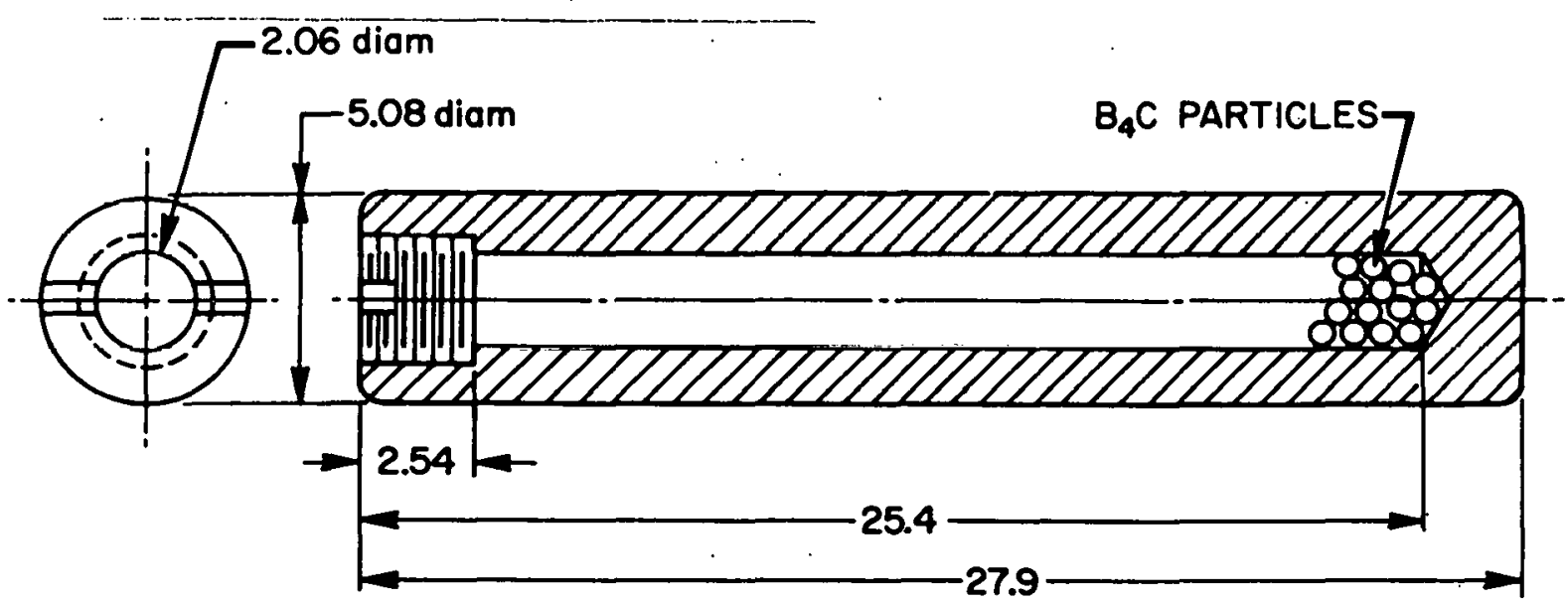

NOTE:

- all dimensions are IN MILLIMETERS

- material is poco graphite

Fig. 4.6. Particle holder for the evaluation of lumped burnable poison (LBP) and the reserve shutdown control (RSC)--coated $B_{4} C$ particles. 


\subsubsection{Dosimetry and Flux Monitors}

Appropriate dosimetry will be placed in each graphite body of HRB-21. The dosimetry materials will be such that the total fluence, the thermal fluence, and the fast neutron fluence can be determined by postirradiation analysis of the dosimetry.

\section{IRRADIATION CONDITIONS}

\subsection{IRRADIATION TEMPERATURE}

Capsule HRB-21 has a target volumetric fuel average temperature of $975^{\circ} \mathrm{C}$. The graphite body radial gaps have been specified to maintain this temperature as uniformly as possible over the length of the capsule. Fuel compact temperatures will be inferred from the graphite thermocouple temperature data and the preirradiation design thermal analysis. Inreactor temperature control will be maintained by adjusting the neon and helium concentrations in the sweep gas. After irradiation and completion of the fuel/graphite metrology, a detailed thermal analysis will be performed to obtain in-reactor fuel compact temperatures.

A total of 24 thermocouples will be placed in the graphite fuel bodies to monitor temperatures during the irradiation. Within each fuel body, three thermocouple junctions will be located on an axial plane as close as possible to the midpoint of each $50-\mathrm{mm}$-long fuel compact. The thermocouple arrangement is shown in Fig. 5.1. The expected fuel operating temperature uncertainty during irradiation may be as high as $\pm 150^{\circ} \mathrm{C}$ because of the lack of temperature monitors within the fuel compacts themselves. This uncertainty is expected to be reduced to $\pm 60^{\circ} \mathrm{C}$ after postirradiation metrology and completion of the detailed thermal analysis. The average graphite operating temperature is expected to be about $650^{\circ} \mathrm{C}$.

\subsection{FUEL BURNUP}

The HRB-21 fuel fissile- and fertile-particle burnup estimates have been made using the CACA-2 fuel depletion code ${ }^{4}$ for a six-cycle irradiation 


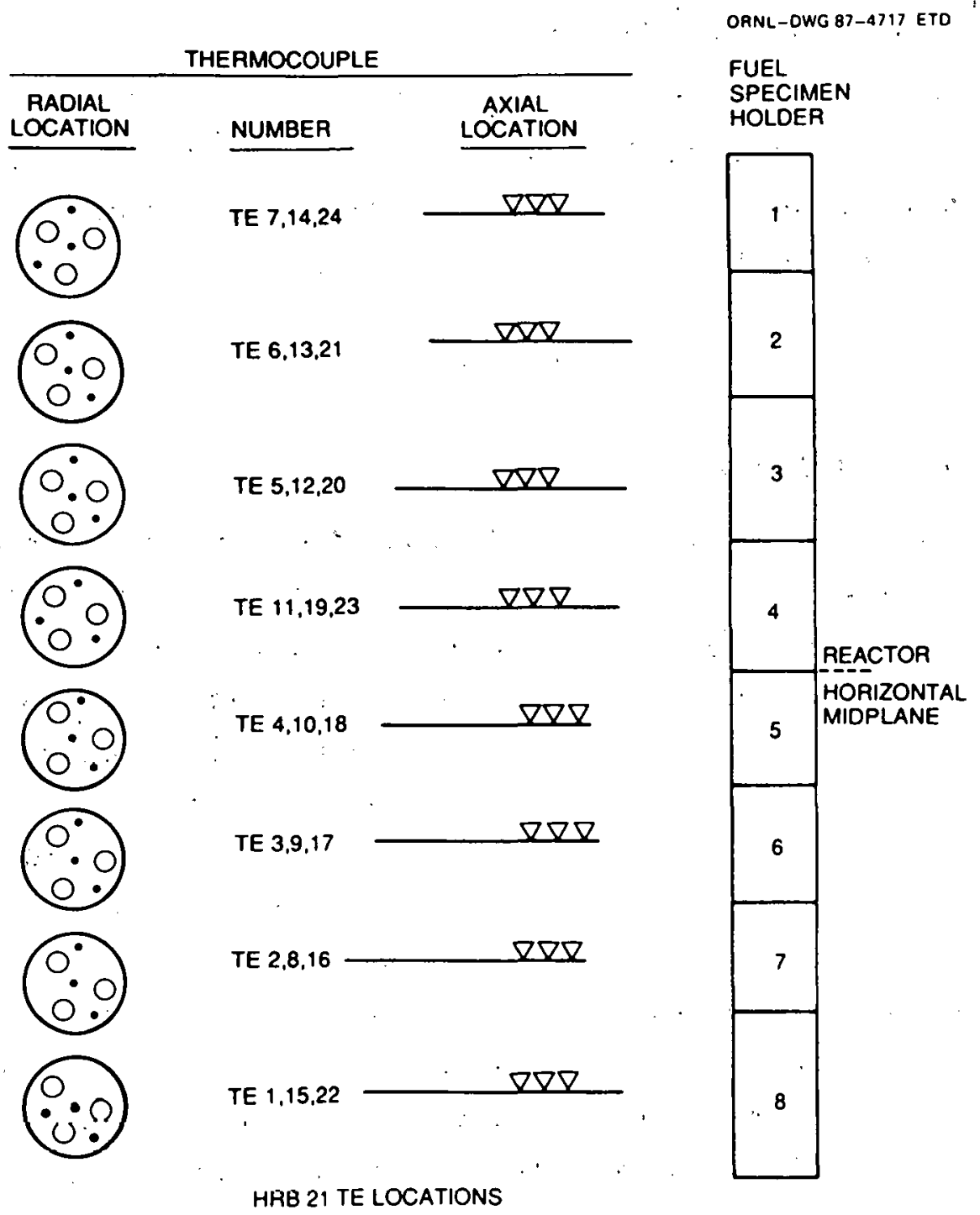

Fig. 5.1. Thermocouple arrangement in irradiation capsule HRB-21.

in the HFIR Removable Beryllium Reflector Irradiation (RB*) facility. The maximum expected end-of-life burnup near the HFIR midplane (positions 4 and 5) is 24.48 FIMA for the fissile fuel and 2.78 for the fertile fuel. The minimum expected end-of life burnup at the graphite body positions. 1 and 8 is 15.58 fissile and 0.78 fertile. The expected burnup profiles as a function of irradiation time are shown in Figure 5.2. Calculations of burnup based on dosimetry data and unbonded particle analysis will be performed during HRB-21 postirradiation examinations. 
ORNL-DWG 88-14043
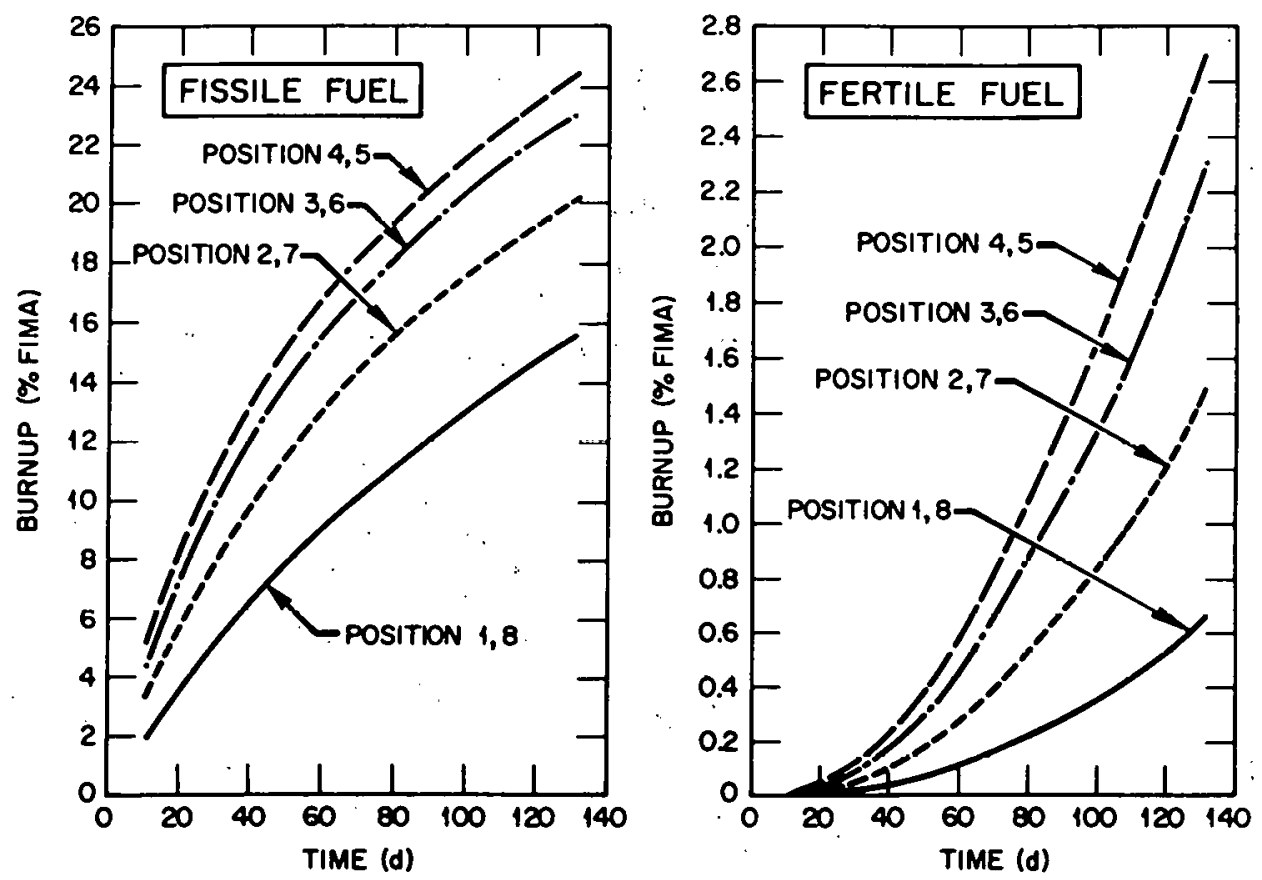

Fig. 5.2. Predicted fissile and fertile particle burnup profiles in capsule HRB-21.

\subsection{FLUENCE}

The expected HRB-21 fast fluence exposure values have been calculated using dosimetry data acquired previously. ${ }^{5}$. Because of the modifications of the $R B *$ facility, the fluence predictions are not known precisely and may be in error by approximately 108. Dosimetry located within the HRB-21 graphite bodies will provide measured flux and energy spectrum values. The predicted fast fluence values as a function of capsule position based on prior data are shown in Fig: 5.3.

\section{POSTIRRADIATION EXAMINATION (PIE)}

After completion of the scheduled 6-cycle irradiation in the HFIR, capsule HRB-21 will be removed from the reactor and allowed to cool in the pool-side facility for 1 to 3 weeks. The capsule will then be loaded into a special transportation cask and moved to the High Radiation Level Examination Laboratory (HRLEL) for disassembly and PTF. 


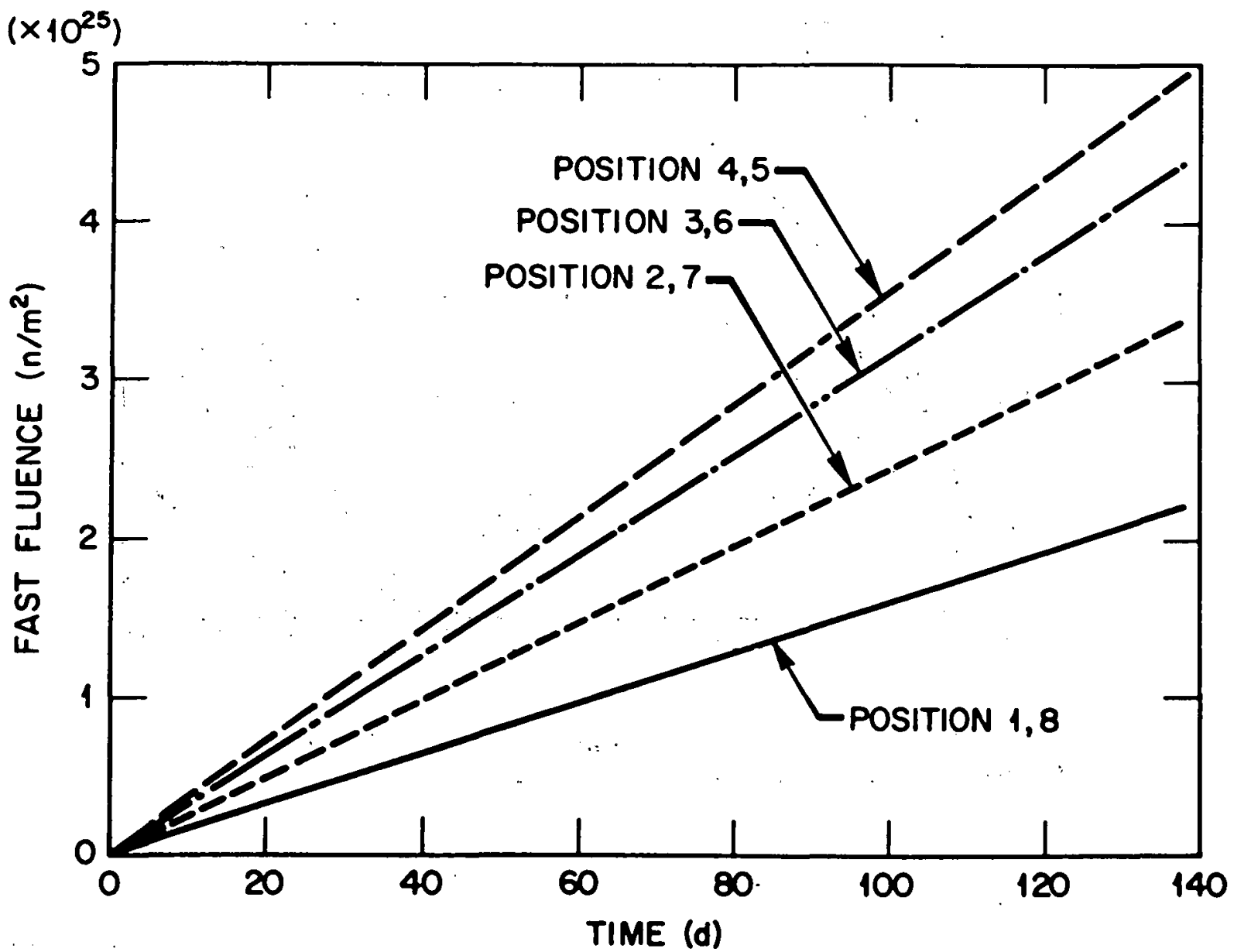

Fig. 5.3. Predicted accumulated fast neutron fluence (E $>29 \mathrm{fJ}$ ) in capsule HRB-21.

Capsule HRB-21 disassembly and PIE will be performed according to a well-defined plan that will be available to the HRLEL staff prior to initiation of PIE. This plan will provide detailed disassembly procedures, and a PIE test matrix and PIE procedures to be used for examination of the irradiated fuel, graphite, and piggyback specimens.

The irradiated specimens will be removed from the capsule containments by making circumferential cuts at the top and bottom of the fueled portion of the capsule. (Engineering drawings with indicated cuts will be supplied in the PIE plan.) At this point the thermocouple arrays will be removed 
and stored for further analysis if necessary. The circumferential cut surfaces will be deburred, and the carbon insulators and graphite fuel bodies will be removed by pushing them out onto a clean positioning tray. The insulators and graphite bodies will be visually examined and photographed, and any unusual areas will be noted. Dimensional measurements. will be determined on the insulators, and graphite bodies at various locations that will permit direct comparison with preirradiation dimensions. These data will be used in the postirradiation thermal analysis. Each fuel body will then be stored in a properly identified individual container for further disassembly and PIE. The primary and secondary containments will also be stored in properly identified containers for further analysis.

For each graphite fuel body, the encapsulated specimens--dosimeters, sorptivity specimens, and unbonded particle specimens-will be extracted by removing the screw caps holding them in place. The sorptivity specimens and dosimetry specimens will be stored in properly identified containers to be examined later by high-resolution gamma spectrometry to determine activation product inventories. The standard and defective unbonded particle specimens will be removed in a similar fashion and stored in properly identified containers. The unbonded particles will be. removed from the niobium encapsulation with the container gas content measured upon opening. After removal, the unbonded particles will be subjected to visual and irradiated-microsphere gamma analyzer (IMGA) examinations to establish failure levels.

For a limited number of graphite fuel bodies (tentatively bodies 5,6 , and 8 ), the irradiated fuel compacts will be unloaded by removing the screw caps holding them in place at the bottom of the body. The compacts will be visually examined and photographed, and any unusual areas will be noted. Diameter and length measurements at several locations will be made along the compact length to establish irradiation-induced shrinkage for use in the postirradiation thermal analysis. After fuel-compact removal, the bonding strength of the upper fuel-closure plugs (cemented in place at time of fabrication) will be measured by a pushout test using a force gage. 
The fuel compacts from fuel bodies 5, 6, and 8 will be subjected to detailed examinations to establish the fraction of particles with (a) totally failed coatings and (b) failed SiC but intact outer PyC coatings. A tentative PIE test matrix for these compacts is provided in Table 6.1.

Table 6.1. Tentative PIE test matrix for eight. fuel compacts

\begin{tabular}{|c|c|c|c|c|c|c|c|}
\hline \multirow{2}{*}{ Compact } & \multicolumn{2}{|l|}{ TRIGA } & \multirow{2}{*}{$\begin{array}{l}\text { Total } \\
\text { failure }\end{array}$} & \multirow{2}{*}{ IMG̣A } & \multirow{2}{*}{$\begin{array}{c}\text { TRIGA } \\
\text { reactivation }\end{array}$} & \multirow{2}{*}{$\mathrm{CCT}$} & \multirow{2}{*}{$\begin{array}{l}\text { Post-CCT } \\
\text { exam }\end{array}$} \\
\hline & Activation & Metallography & & & & & \\
\hline 9 & 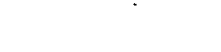 & & & & & $\mathrm{x}$ & $\mathrm{x}$ \\
\hline 2 & & & & & $\mathrm{X}$ & $\mathrm{x}$ & $\mathrm{x}$ \\
\hline 3 & · & 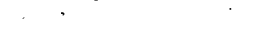 & & & & $\mathrm{x}$ & $x$ \\
\hline 4 & · & & & & $\mathrm{x}$ & $\mathrm{x}$ & $\mathrm{x}$ \\
\hline 5 & $\mathrm{x}$ & $\mathrm{x}$ & $\mathrm{x}$ & $\mathrm{x}$ & & & $\cdot$ \\
\hline 6 & $\mathrm{x}$ & $\mathrm{x}$ & $\mathrm{x}$ & $\mathrm{x}$ & & & \\
\hline 7 & & . & . & . & $\mathrm{x}$ & $\mathrm{X}$ & $\mathrm{X}$ \\
\hline 8 & $\mathrm{X}$ & $\mathrm{X}$ & $\mathrm{X}$ & $\mathrm{X}$ & & & \\
\hline
\end{tabular}

The integrity of as-irradiated fuel particles heated in the CCT program can be assessed by the initial release profiles measured as the CCT sample are brought to test temperature (prior to high-temperature induced failure). For example, adequately low releases (in agreement with model expectations) during both in-reactor operations and during heatup to $1600^{\circ} \mathrm{C}$ (and for an expected time thereafter) is a direct demonstration of the retentive capability of the fuel for MHTGR service.

\subsection{CONDUCTION COOLDOWN TESTING}

A conduction cooldown test facility (CCTF) is being constructed at ORNL to provide simulation of the conditions of MHTGR LBEs and measurement of fuel failure and fission-product release. The majority of the HRB-2I graphite bodies will be subjected to postirradiation heating tests in the CCTF. Since the methods validation program for normal operating conditions 
will examine, in-reactor performance at temperatures up to $1250^{\circ} \mathrm{C}$, the CCTs will emphasize the temperature range of 1400 to $1800^{\circ} \mathrm{C}$.

A final allocation of samples within the postirradiation test matrix depends upon HRB-21 in-reactor fuel performance results. A tentative CCT matrix for HRB-21 samples, which assumes in-reactor performance that meets MHTGR release limits, is given in Table 6.2. For planning purposes, the

Table 6.2. Tentative CCT matrix for HRB-21 samples

\begin{tabular}{|c|c|c|c|c|c|c|}
\hline \multirow{2}{*}{$\begin{array}{c}\text { Test } \\
\text { No. }\end{array}$} & \multirow{2}{*}{$\begin{array}{c}\text { Body } \\
\text { No. }\end{array}$} & \multirow{2}{*}{$\begin{array}{l}\text { Heating } \\
\text { temperature } \\
\left({ }^{\circ} \mathrm{C}\right)\end{array}$} & \multicolumn{2}{|c|}{ Average \& FIMA } & \multicolumn{2}{|c|}{ Number of particles } \\
\hline & & & Fissile & Fertile & Fissile & Fertile \\
\hline 1 & 9 & 1600 & 15.5 & 0.7 & 6,700 & 13,310 \\
\hline 2 & 2 & 1400 & 20.2 & 1.5 & 5,540 & 13,310 \\
\hline 3 & 7 & 1800 & 20.2 & 1.5 & 5,540 & 13,310 \\
\hline 4 & 3 & 1600 & 23.0 & 2.3 & 4,070 & 13,310 \\
\hline 5 & 4 & 1600 & 24.4 & 2.7 & 3,380 & 13,310 \\
\hline \multicolumn{2}{|c|}{ Total } & & & & 25,230 & 66,550 \\
\hline
\end{tabular}

CCT times are estimated to be $1000 \mathrm{~h}$ for tests at temperature of less than or equal to $1600^{\circ} \mathrm{C}$ and $500 \mathrm{~h}$ for tests at a temperature greater than $1600^{\circ} \mathrm{C}$. The actual test times will be determined jointly by the test engineer in consultation with the data analyst based on the observed fission product release in each test, the furnace capabilities, and the data needs for model validation purposes.

\section{TENTATIVE SCHEDULE}

The following tentative schedule for capsule HRB-21 is planned. This schedule is a target schedule subject to HFIR startup and shutdown requirements and interference from other experiments in the HRLEL. 
Completion date

\author{
Capsule HRB-21 planining \\ Complete fuel/graphite fabrication. \\ Complete capsule assembly \\ Insert HRB-21' in HFIR '. \\ Remove $\mathrm{HRB}-21$ from HFIR \\ Complete disassembly/metrology \\ Complete "thermal analysis \\ Complete postirradiation examination \\ Conductión cooldown tests \\ Complete topical report
}

\author{
September 1987 \\ December 1987 \\ November 1988 \\ July 1989 \\ December 1989 \\ April 1990 \\ November 1990 \\ June 1991 \\ September 1991 \\ February 1992
}

\section{REFERENCES}

1. Project Staff, Modular HTGR Plant Fuel/Fission Product Technology Development Plan, Rev. 1, DOE-HTGR-86-027, April 1987.

2. D. C. Elrod, G. F. Giles, and W. D. Turner, HEATING6: Multidimensional Heat Conduction Analysis With The Finite-Difference Formulation, ORNL Radiation Shielding Information Center Documentation for RSIC Code Package PSR-199, Feb. 1, 1985.

3. C. C. Adams, Defect Fractions for Fissile and Fertile TRISCOCoated Fue1, HTGR-86-082, September 1986.

4. E. J. Allen, CACA-II; Revised Version of CACA-1 Heavy Isotopes and Fission Product Concentration Calculational Code for Experimental Irradiation Capsules, ORNL/TM-5266, February 1976.

5. Gas-Cooled Reactor Programs, High-Temperature Gas-Cooled Reactor Technology Development Program. Annual Progress Report for Period Ending December 31, 1981, ORNL-5871, December 1.981 . 
DOE-HTGR - 87-091

ORNL/TM- 10987

Distribution

Category UC-522

\section{INTERNAL DISTRIBUTION}

1-2. Central Research Library

3. Document Reference Section

4-5. Laboratory Records Department

6. Laboratory Records, ORNL RC..

7. ORNL Patent Section

8-10. M\&C Records Office

11. C. A. Baldwin

12. W. P. Barthold (Consultant)

13. E. E. Bloom

14. J. A. Bucholz

15. T. D. Burchel1

16. J. C. Cleveland

17. W. P. Eatherly (Consultant)

18. L. C. Emerson

19. E. C. Fox

20. U. Gat

21. R. K. Genung
22. J. R. Hightower

23. F. J. Homan

24. D. T. Ingersoll

25: J. E. Jones, Jr.

26-30. M. J. Kania

31. P. R. Kasten (Consultant)

32. A. L. Lotts

33: J. C. Mailen

34. B. F. Myers

35. F. R. Mynatt

36. N. H, Packan

37-42. B. W. Patton

43. P. L. Rittenhouse

44. J. P. Sanders

45. K. R. Thoms

46. D. B. Trauger

47. A. Zucker

EXTERNAL DISTRIBUTION

48-50. DOE, DIVISION OF HTGRs, NE-451, Washington, DC 20545

J. E. Fox

M. E. Long

A. C. Millunzi

51. DOE, OFFICE OF ADVANCED REACTOR PROGRAMS, NE-45, Washington, DC 20545

Director

52. DOE, SAN, 1333 Broadway, Oakland, CA 94612

S. Wookey

53. DOE, OAK RIDGE OPERATIONS OFFICE, P.O. Box 2001, Oak Ridge, TN $37831-8600$

Office of Energy Research and Development

J. W. Cooke 
54. GENERAL ATOMICS, P.O. Box 85608, San Diego, CA 92138-5608 A. J. Neylan

55. MODULAR HTGR PLANT DESIGN CONTROL OFFICE, P.O. BOX 85608, San Diego, CA 92138-5608

R. R. Mills

56-112. DOE, OFFICE OF SCIENTIFIC AND TECHNICAL INFORMATION, Office of Information Services, P.0. Box 62; Oak Ridge, TN 37831

For distribution as shown in TIC-4500, Distribution Category UC-522 (Gas-Cooled Reactor Technology) 